\title{
Security and citizenship in the global South: In/securing citizens in early republican Turkey (1923-1946)
}

\section{Pinar Bilgin and Basak Ince}

Bilkent University

\begin{abstract}
The relationship between security and citizenship is more complex than media portrayals based on binary oppositions seem to suggest (included/excluded, security/insecurity), or mainstream approaches to International Relations (IR) and security seem to acknowledge. This is particularly the case in the post-imperial and/or postcolonial contexts of global South where the transition of people from subjecthood to citizenship is better understood as a process of in/securing. For, people were secured domestically as they became citizens with access to a regime of rights and duties. People were also secured internationally as citizens of newly independent 'nation-states' who were protected against interventions and/or 'indirect rule' by the (European) International Society, whose practices were often justified on grounds of the former's 'failings' in meeting the so-called 'standards of civilization'. Yet, people were also rendered insecure as they sought to approximate and/or resist the citizen imaginaries of the newly established 'nation-states'. The article illustrates this argument by looking at the case of Turkey in the early Republican era (1923-1946).
\end{abstract}

\section{Keywords}

citizenship, global South, International Society, security, standards of civilization, Turkey

\section{Introduction}

The relationship between security and citizenship is more complex than media portrayals based on binary oppositions seem to suggest (included/excluded, security/insecurity), or mainstream approaches to International Relations (IR) and security seem to acknowledge (insecurity originates from outside the state boundaries, and states provide security

\section{Corresponding author:}

Pinar Bilgin, Bilkent University, 6800 Ankara, Turkey.

Email: pbilgin@bilkent.edu.tr 
for 'individuals qua citizens'). ${ }^{1}$ On the one hand, access to citizenship rights has brought betterment to peoples' lives, regardless of however relative such betterment has proven to be. Throughout the twentieth century, individuals and social groups constituted their agency as they struggled to gain citizenship rights. On the other hand, citizens continued to experience insecurities even after the transition from subjecthood to citizenship.

The relationship between security and citizenship is particularly complicated in the post-imperial ${ }^{2}$ and/or postcolonial contexts of global South. ${ }^{3}$ In such contexts, the transition of individuals and social groups from subjecthood to citizenship is better understood as a process of in/securing - that is, neither as a moment of security, as official state discourses proclaim, nor as a process of insecuring, as their critics contend. We use the term 'in/securing' to underscore the reflexivity of security, that is, the ways in which our practices produce 'insecurity' as well as 'security' for ourselves and for others. ${ }^{4} \mathrm{We}$ understand 'security' as 'the condition of being and feeling safe', 5 and 'insecurity' in terms of both specific and/or military threats and non-specific and/or non-military threats. ${ }^{6}$

As part of the process of transition from subjecthood to citizenship, people in the global South were secured domestically since they no longer were imperial and/or colonial subjects, but citizens with access to a regime of rights and duties. People were also secured internationally as citizens of newly independent 'nation-states' who were protected against interventions and/or 'indirect rule' by members of the (European) International Society, whose practices were often justified on grounds of the former's 'failings' in meeting the so-called 'standards of civilization'. Yet, people were also rendered insecure as they sought to approximate and/or resist the citizen imaginaries of the newly established 'nation-states'. Those who did not fit the 'model citizen' mould of the new 'nation-states' experienced myriad insecurities. ${ }^{7}$ Security guarantees introduced as part of the citizenship regimes of the 'nation-states' usually coexisted with insecurities generated as part of the dynamics of transition processes, or by the institutional and ideational legacies of imperialism and/or colonialism. ${ }^{8}$

In offering this argument, we build on a notion of 'postcoloniality' understood 'as a subjectivity of oppositionality to imperializing/colonializing (read: subordinating/ subjectivizing) discourses and practices' and 'not so much subjectivity "after" the colonial experience'. ${ }^{9}$ By adopting such a broad notion of 'postcoloniality', we seek to underscore the relevance of the insights of Postcolonial Studies in understanding the insecurities of not only those who were colonized but also others who were caught within the material and non-material structures of colonialism or imperialism.

For, even in those parts of the world that did not experience colonization, inquiring into the 'postcolonial anxieties' of the elite ${ }^{10}$ is likely to offer important insights. A case in hand is the so-called 'standards of civilization'. ${ }^{11}$ During the nineteenth and early twentieth centuries, the 'standards of civilization' set by the (European) International Society ${ }^{12}$ were utilized by the European great powers in managing their relations with 'non-Europe' (as with the imposition of unequal treaties, indirect rule and/or League of Nations mandate regimes). These 'standards' allowed the European great powers to regulate their relations with 'non-Europeans', usurp raw materials and open up markets for their products and services. ${ }^{13}$ The European great powers' practices as such left their 
mark on not only those who were colonized but also other 'non-Europeans' whose relations with 'Europe' were shaped by these 'standards'. ${ }^{14}$

As an illustration, we look at the early Republican period in Turkey (1923-1946). ${ }^{15}$ Turkey may come across as a curious choice to illustrate our argument. The Republic of Turkey was established in 1923, following a war of national liberation that was fought in resistance to the Sèvres Treaty of 1918, which was designed to carve out the Ottoman Empire in the aftermath of World War I. Turkey narrowly escaped dismemberment and, unlike some other post-Ottoman territories, evaded the imposition of the League of Nations mandate. ${ }^{16}$ Western-oriented since its founding, ${ }^{17}$ Turkey joined the North Atlantic Treaty Organization in 1952, and became a European Community associated country in 1963. Finally, yet importantly, Turkey carries its own imperial baggage visa-vis other post-Ottoman peoples. ${ }^{18}$ In other words, Turkey does not come across as a 'typical' case to illustrate insecurities in the global South. Yet, as we suggest below, considering the insecurities of Turkey's early Republican elite offers insights into the complex relationship between citizenship and in/security in the global South. ${ }^{19}$

Relatively few scholars have thus far drawn upon Postcolonial Studies to study the Ottoman Empire and Turkey. Building on Deringil's research on late Ottoman postcolonial anxieties, ${ }^{20}$ we suggest that adopting postcolonial lenses provide fresh insight into the practices of Turkey's early Republican leaders who inherited these anxieties. For, while the Lausanne Treaty of 1923 had affirmed Turkey's sovereignty, independence and territorial integrity, the early Republican leaders were nevertheless concerned about the fragility of such recognition against the background of the (European) International Society's ambivalence towards the Ottoman 'difference'. The Ottoman Empire was a multi-ethnic body organized around communities of faith (the so-called Millet system). In the absence of a citizenship regime, the European great powers voiced their scepticism about the Ottomans' ability to govern non-Muslim communities in general and Christian peoples in particular. Turkey's early Republican leaders were met with similar expressions of scepticism (see below) in their early encounters with the International Society. Arguably, their quest for a unified body politic and creating a 'nation-state' was as much a product of their ideas and ideals ${ }^{21}$ as it was a part of the attempt to meet the 'standards of civilization' of the International Society. ${ }^{22}$

Consider, for instance, how Turkey's early Republican leaders framed their efforts directed towards creating a 'nation-state' in 'civilizational' terms. In a speech delivered on the 10th Anniversary of the Republic, Mustafa Kemal (Atatürk) described the Republican leadership's goals in the following manner:

We will raise our country to the level of the most developed and most civilized countries. We will make our nation have the means and sources of utmost prosperity. We will raise our national culture above the contemporary civilization. ${ }^{23}$

Rather than rejecting the discourse of 'standards of civilization' that temporalized difference and spatialized time (see below), the Republican leaders sought to locate Turkey in this 'civilization'. Yet at the same time, the very 'civilization' they sought to locate Turkey in was represented as a source of insecurity. In a text no less significant than Turkey's national anthem, which was adopted during the war of national liberation, the 
European great powers are referred to as the 'single-fanged monster you call civilization'. ${ }^{24}$ Our point being, given Turkey's early Republican leaders' ambivalence vis-a-vis 'Europe', and the anxieties they shared with the postcolonial, there are potential insights to be gained from adopting postcolonial lenses in studying Turkey's case.

Section titled 'From subjecthood to citizenship: a process of in/securing' introduces our twofold argument. First, we suggest that individuals' transition from subjecthood to citizenship in the post-imperial and/or postcolonial contexts of the global South should be understood less as a moment of security, or as producing mostly insecurity, but a process of in/securing. ${ }^{25}$ Second, we suggest that processes of transition from subjecthood to citizenship in such contexts cannot be captured by focusing on the domestic dynamics alone, but should be studied by locating those dynamics in the international context. Here, we refine the 'included' v. 'excluded' binary by offering the category of 'included/ excluded' in reference to those citizens who were insecured by virtue of their late access to some citizenship rights and/or their lack of sense of empowerment in exercising those rights. Section titled 'Rethinking the literature on citizenship in Turkey' locates our argument vis-a-vis the literature on citizenship in Turkey, which offers rich micro-accounts that are yet to be brought together to offer a macro-account on all citizens' experiences of in/security. The following section looks at Turkey's 'included/excluded' citizens' experiences of in/security during the period under consideration. We discuss the governmental efforts directed at territorializing the country and introducing civic education courses in primary and secondary schools. Section titled "Turkey's "Model Citizens": Searching for “'Ontological Security”?' considers the 'ontological insecurity' of Turkey's 'model citizens' who were not excluded from access to citizenship rights, but were nevertheless rendered insecure as they became increasingly less able to live with 'difference'. Here, we focus on the infamous 'Citizen, Speak Turkish!' campaign of the late 1920 s and early 1930s.

\section{From subjecthood to citizenship: a process of in/securing}

Students of critical theorizing about International Relations and security ${ }^{26}$ have challenged the assumptions that states unfailingly provide security to their citizens and that insecurity originates from non-citizens. ${ }^{27}$ They have also challenged the presumption that states primarily (if not exclusively) have responsibilities towards their own citizens. ${ }^{28}$ Somewhat more recently, such critique has become central to debates in critical theorizing on border security, surveillance and immigrants. ${ }^{29}$ The insecurities experienced by citizens have also been examined in the Citizenship Studies literature, which has looked at the exclusionary and discriminatory practices of states, ${ }^{30}$ and the Political Geography literature on the 'whereness of citizenship'. ${ }^{31}$ There is also the Postcolonial Studies scholarship, which has considered insecurities of the postcolonial. ${ }^{32}$ The argument here builds on the insights of these four bodies of literature and focuses on the relationship between security and citizenship in the global South.

The institution of citizenship regimes against the background of decaying empires and/or colonial regimes is rightly viewed as a moment of celebration. However, such processes of transition from subjecthood to citizenship are also riddled with insecurities. 
This is the case not only for those who are excluded from the citizenship regimes of newly established states but also for those who are not. One such instance of in/securing can be found in the early experiences of the United States, as analysed by Marston:

Although citizenship has been a conceptual foundation in the building of the American state, it is a category of status whose historical (and contemporary) access has been mediated through deep-seated prejudices, such as racism and sexism, and moulded by strongly held beliefs about the 'natural' roles of men and 'others'. ${ }^{33}$

Among others, women's experiences in different parts of the world has shown that the removal of legal barriers is only a necessary first step - important but not enough in itself so long as other barriers remain and/or are instituted in the transitory process. ${ }^{34}$ Indeed, as Secor underscored, over the years:

the discourse and practice of citizenship [has universalised] the particular constellation of dominant positions (such as maleness, bourgeois status, or identification with the titular ethnic or racial group) that is occupied by 'the citizen', defining those identities that are not encompassed within the seemingly neutral category as particularistic and therefore properly excluded from expression within the public sphere. ${ }^{35}$

Hence, Sibley maintained that 'apart from examining legal systems and the practices of social control agencies, explanations of exclusion require an account of barriers, prohibitions and constraints on activities, from the point of view of the excluded' ${ }^{36}$

Our analyses need not stop at examining exclusionary practices, cautioned Sibley, but consider all practices of citizenship. This is because, he argued:

[a] study of exclusion ... is necessarily concerned with inclusion, with the 'normal' as much as the 'deviant', the 'same' as well as the 'other' and with the credentials required to gain entry to the dominant groups in society. ${ }^{37}$

To this end, we offer a threefold categorization: (1) those who are 'excluded' from the citizenship regimes of 'nation-states', (2) those 'model citizens' who are 'included' by agreeing to approximate the citizen imaginary, and (3) those who are 'included/excluded' due to their resistance or late/r access to citizenship rights, or a lack of sense of empowerment in exercising those rights. ${ }^{38}$ This threefold categorization allows us to study the multiple ways in which citizens are in/secured as they seek to approximate or resist the citizen imaginary of 'nation-states'.

We further suggest that processes of transition from subjecthood to citizenship in the global South could be better understood when located in their international context. In offering this argument, we build upon Hindess' analysis of citizenship as a 'conspiracy against the rest of the world'. ${ }^{39}$ Citizenship is a 'conspiracy', Hindess argued, by virtue of:

bringing together members of particular subpopulations and promoting some of their interests, but also ... rendering the larger population governable by dividing it into subpopulations consisting of the citizens of discrete, politically independent and competing states. ${ }^{40}$ 
While this 'conspiracy' has taken the form of an 'international system of population management' 41 in Western Europe and North America, it has unfolded differently in the global South. ${ }^{42}$

In the global South, the dynamics of the 'conspiracy' have historically been conditioned by the global disparities in power/knowledge and anxieties generated by the temporalization of difference and spatialization of time. The temporalizing of difference relegated 'peoples and ways of life to the status of anachronisms' by virtue of their differences. ${ }^{43}$ The spatializing of time involved representing some parts of the world as belonging to the past. ${ }^{44}$ Many in the global South were introduced to citizenship as part of their struggles against Orientalism's 'geographical violence'. ${ }^{45}$ During the age of colonialism, the European great powers pointed to the absence of notions and institutions citizenship in some parts of the world as a moral, intellectual and institutional failure and portrayed such 'failures' as evincing their inability to self-govern in a 'civilized' manner. ${ }^{46}$ It was based on such apparent 'failings' of some in meeting the 'standards of civilization' that the members of the (European) International Society justified the need for colonial rule in some places, differentiated treatment of peoples under International Law in other places and/or the need for reform in some other places. ${ }^{47}$

Following decolonization, those who used to be on the receiving end of such practices sought to build their own 'nation-states' and mould the former subject peoples in their image of 'model citizen'. ${ }^{48}$ Of the citizens of the newly established 'nation-states', both those who sought to resist and those who sought to approximate the new citizen imaginary were in/secured - albeit in different ways. Our intention here is not to underplay the significance of the emancipatory dimension of such processes. Nor do we mean to trivialize the ideas and ideals of the intellectuals in the global South. Rather, we underscore the international context in which their agency is constituted. In offering this argument, our aim is to understand the ways in which the policy-makers' practices of citizenship in the global South produce security and insecurity for the citizens as they respond to (and shape) domestic and international dynamics. ${ }^{49}$

\section{Rethinking the literature on citizenship in Turkey}

There has now evolved a substantial body of literature on citizenship in Turkey, detailing the predicament of those who were 'excluded' through the population exchange of 1923 (the Mübadele) whereby the Greek Orthodox Christians from Turkey left for Greece, and the Muslims from Greece came to Turkey. ${ }^{50}$ The discriminatory practices experienced by those who became citizens of the Republic are also examined in rich micro-accounts on the Kurds, ${ }^{51}$ the Alevi, ${ }^{52}$ and the minorities as defined in the Treaty of Lausanne. ${ }^{53}$ In what follows, we present an overview of the literature by grouping existing studies into two accounts: those who consider the citizenship regime of the Republic as a moment of security for all; and those see it as a process of insecuring of some.

In the literature on citizenship in Turkey, those who consider the 1924 Constitution $^{54}$ as marking a moment of security base their argument on the following definition of citizenship as found in Article No.88: 'The people of Turkey, regardless of their religion and race, are Turkish in terms of citizenship'. ${ }^{55}$ The 1924 Constitution could indeed be viewed as having laid the foundations of an inclusive citizenship regime by recognizing 
the 'minority' status of the Greek Orthodox, ${ }^{56}$ Jewish and Armenian Orthodox peoples. ${ }^{57}$ This first account acknowledges that, in time, there emerged a gap between what the 1924 Constitution laid down on paper and the citizenship practices of the state. ${ }^{58}$ Nevertheless, the first account explains away this gap as an effect of the aberrations of some bureaucrats. Put differently, the first account takes the founding texts of the Republic at face value, and views the insecurities experienced by some citizens as exceptions to an otherwise inclusive citizenship regime.

The first account also credits the Republic's citizenship regime for having instituted a notion of citizenship as found in other 'civilized' countries. As such, these authors seem to situate the efforts of the early Republican leaders vis-a-vis the international context. They nevertheless underplay the challenging nature of the international context of this period and the postcolonial anxieties of Turkey's policy-makers. Yet, the domestic discourses of Turkey's Republican elite indicate that such anxieties were not far from their thoughts. For instance, the minutes of the debates on the adoption of the (Swiss) civil code in Turkey (which also meant the secularization of the civil code) include references to the risk of intervention by European great powers on behalf of the minorities unless the civil code was secularized. ${ }^{59}$ Our point being that the first account fails to appreciate how the 1924 Constitution helped to secure the citizens of the Republic of Turkey against those members of the (European) International Society who did not hesitate to express their doubts regarding Turkey's capacity to govern its populace in a 'civilized' manner. ${ }^{60}$

The second account offers an important corrective by laying bare the ways in which the early Republican citizenship regime was a far cry from being the moment of security it is portrayed to be by the first account. It was a process of insecuring of some, argue these authors, pointing to an exclusionary pattern in the citizenship practices of this era. ${ }^{61}$ Such practices included the withholding of women's political rights until 1934, ${ }^{62}$ barring non-Turkish speakers from government and private sector jobs for many years, ${ }^{63}$ subjecting minority citizens to discriminatory treatment in war-time taxation and conscription ${ }^{64}$ and the settling of immigrants and citizens in line with statist security concerns. ${ }^{65}$

While providing immensely valuable micro-accounts on the experiences of insecurity by various aspects of Turkey's citizenry, the second account has focused on the domestic struggles and overlooked the international. Consequently, the first account has not considered the multiple ways in which all citizens were secured and insecured vis-a-vis domestic and international threats during this period. In the absence of such a macro-account bringing together these micro-accounts, we do not have a comprehensive understanding of the complex relationship between security and citizenship in Turkey in the early Republican era.

We submit that in Turkey, as in other global South contexts, the transition of individuals and social groups from subjecthood to citizenship is better understood as a process of in/securing. Our argument deviates from the first account that views the transition as marking a moment of security for all. It is also different from the second account that considers the transition as a process of insecuring for some. We suggest that, on the one hand, the new Republic's citizenship imaginary and practices of citizenship secured Turkey's people as citizens of an independent and sovereign 'nation-state'. No longer were they subjects of an Empire; nor did they face the danger of being subjected to the indirect rule or mandate administration by the European great powers due to their 
failings in meeting the 'standards of civilization'. On the other hand, people were also rendered insecure by the Republic's citizen imaginary. For, only those who choose (and/ or were able) to approximate the citizen imaginary (i.e. the 'included') exercised full citizenship rights. Turkey's 'included/excluded' citizens did not always feel capable or empowered to make use of rights that were available to them on paper. Furthermore, as evinced by the infamous 'Citizen, Speak Turkish!' campaign (see section titled 'Turkey's "Model Citizens": Searching for "Ontological Security”?'), even the 'included' were insecured as they became less able to live with 'difference'.

\section{Turkey's 'Included/Excluded' citizens}

The 1923 Mübadele (population exchange) marked the beginning of the process of in/ securing in the new Republic. Those people we referred to as the 'excluded' were exchanged with Greece in accordance with the Lausanne Treaty. ${ }^{66}$ The population exchange was designed by the Norwegian diplomat Fridtjof Nansen, the League of Nations High Commissioner for Refugees, and was lauded by the (European) International Society as guaranteeing the protection of minorities towards preventing future conflicts. ${ }^{67}$ In 1922, Nansen received the Nobel Peace Prize for his contributions to the repatriation and asylum search for the refugees fleeing the war in Russia and Asia Minor. Constructing an "'unmixed" Near East' was the central goal of his mission to Greece and Turkey. ${ }^{68}$ The point being that the 'excluded' were products of not only the citizenship imaginary of the new 'nation-state' in Turkey but also the minority and conflict regulation practices of the (European) International Society.

Insecurities of those who were subjected to the population exchange of 1923 are well documented in the academic literature as well as popular culture - as with the following poem by Papa Neofitos Ekonomos (1925):

İsmet Pasha and Venizelos came

They decided on a bargain

When doing this did they ask any man?

We'd not seen the like since the world began

They expelled us from Turkey

Tears flowed like blood from all our eyes. ${ }^{69}$

This and the following sections ('Turkey's "Included/Excluded" citizens' and 'Turkey's "Model Citizens": Searching for "Ontological Security"?') look at the ways in which those who were not excluded from the new Republic's citizenship regime were in/ secured. The next section discusses the 'ontological security' of Turkey's 'model citizens' (the 'included') and the roles they played in the infamous 'Citizen, Speak Turkish!' campaigns. This section is concerned with the predicament of the non-Muslim minorities and others who sought to resist the 'ideal' citizen mould ('included/excluded'). Whereas the Lausanne Treaty recognized the 'minority' status of the former, the latter's claim to minority status and/rights (as with the Kurds) was not recognized. ${ }^{70}$ We chose to focus 
on two governmental practices that touched the lives of large numbers of people: namely, the territorialization of Turkey and the establishment of civic education courses in primary and secondary schools.

\section{Territorializing Turkey}

During this era, the practices of territorialization adopted by Turkey's early Republican leaders included the passing of various laws governing who would be allowed to immigrate to Turkey and where the citizens would settle, erasing the remnants and memories of the past inhabitants through settling the immigrants in places vacated by the Armenian and Rum Orthodox subjects of the former Ottoman Empire and the changing of place names throughout Anatolia.

Subjecting the citizens to state-directed movement and settlement measures turned out to be one of the most far-reaching aspects of the practices of in/security of this era. During these years, the Ankara governments passed two settlement laws governing who can immigrate to Turkey and become a citizen, and where the new citizens would be allowed to settle. In 1926, the Law on Settlement No. 885 was adopted. ${ }^{71}$ This law remained in effect until the more extensive Law on Settlement No. 2510 was codified in $1934 .^{72}$

Article No. 2 of the 1926 Law of Settlement addressed the newly arriving immigrants and stated that people who did not belong to the 'Turkish culture' could not be admitted as immigrants or refugees. While Turkish language skills were apparently prioritized in defining the boundaries of the 'Turkish culture', Turkey's Republican leaders nevertheless allowed religious and/or ethnic factors to shape their practices. ${ }^{73}$ The Turkish-speaking immigrants were mostly directed to settle in places where they were expected to help with diluting the non-Turkish speaking population. The non-Turkish-speaking immigrants, in turn, were settled in places that would help with their integration. One exception to this practice was the settlement of the Turkish-speaking immigrants in 'securitysensitive' areas (as with Eastern Thrace, on Turkey's border with Greece and Bulgaria).

The Law on Settlement No. 2510 was less about settling newly arriving immigrants as it was about re-settling non-Turkish speaking and non-Muslim citizens of the Republic. Article No. 2 read:

Turkey is divided into three settlement zones: zone 1 are the areas deemed to be where the population of the Turkish culture is dense ... zone 2 are the areas separated for the migration and settlement of the population deemed to be assimilated into the Turkish culture ... zone 3 are the areas where settlement is prohibited owing to reasons related to health, economy, culture, politics, the military and security. ${ }^{74}$

Whereas Turkish language apparently constituted a key component of the 'Turkish culture' as operationalized by the 1926 law, the 1934 law put emphasis on 'lifestyle'. Article No. 10 of the 1934 law targeted the lifestyle of the nomads in general and the Kurds in particular and abolished all of the previously documented and recognized rights of the tribal chiefdoms and sheikhdoms. ${ }^{75}$ By way of dividing the country into three zones and re-settling the citizens based on their proximity to the 'Turkish culture', the 
1934 law sought, to quote the Grand National Assembly (GNA) lawmakers, to 'create a country speaking with one language, thinking in the same way and sharing the same sentiment'. ${ }^{76}$

Accompanying the two settlement laws were practices that sought to territorialize Turkey by allowing the newly settled citizens to convert the material culture in their places of settlement. The literature on the spatial practices of the early Republican period has mostly focused on the ways on which the new Republic sought to shape the body politic through shaping a new architectural culture. ${ }^{77}$ However, shaping a unified body of citizens may also involve violence directed against the material culture. The evidence of past coexistence and heterogeneity may be (directly) destroyed or (indirectly) allowed to decay through the targeting of elements of the material culture, as with architectural symbols or the urban fabric of cities. ${ }^{78}$ Indeed, Turkey's early Republican leaders chose to settle the immigrants in places vacated by the Armenian and Greek Orthodox subjects of the former Ottoman Empire, thereby giving these re-populated places a makeover. In the process, the remnants of the past inhabitants were erased and the memories of those who were left behind were hurt. ${ }^{79}$

Another aspect of the practices adopted during this period was the changing of place names. During the war of national liberation, place names were changed mostly for emotive reasons, as with the newly liberated towns wishing to reclaim the space. ${ }^{80}$ The changing of place names became a feature of Republican leaders' practices only after the breakup of the Kurdish rebellions in southeastern Anatolia. From the mid-1920s onwards, the practice of renaming was not limited to Greek or Armenian place names but also encompassed those in Arabic and Kurdish as well. ${ }^{81}$

To summarize, the desire to create a unified citizen body through managing the flow of immigrants and their areas of settlement was unmistakable during this period. The settlement practices of the state were not isolated to the immigrants but also involved those citizens who had failed, until then, to approximate the new Republic's citizen imaginary. For instance, the 'model citizen' image of the Republic was imposed on the peoples who were brought up in a nomadic lifestyle. Such imposition of a settled lifestyle, while allowing for provisioning peoples in terms of access to health services and education (security), at the same time rendered apparent the limits of recognition of and respect for (linguistic and lifestyle) difference in the new Republic's citizen imaginary (insecurity). ${ }^{82}$

\section{The civic education courses in primary and secondary schools}

In Turkey, as in other places, the nation-state '[was] inscripted in official documents, histories and journalistic commentaries, among other texts - in ways that impose coherence on what is instead a series of fragmentary and arbitrary conditions of historical assemblage'. ${ }^{83}$ In early Republican Turkey, practices to this effect included the propagation of the so-called Turkish History thesis, ${ }^{84}$ the language reform that involved the transition from Arabic to Latin alphabet and ridding Turkish of Arabic and Persian words and the changing of peoples' surnames into Turkish. The most emblematic of them all for our purposes was the introduction of a compulsory civic education course in the primary and secondary schools. Since this course served the purpose of introducing, 
justifying and cementing all of the other cultural practices, this section of the article will focus on the civic education course. ${ }^{85}$

The name of the civic education course was Yurt Bilgisi (Homeland Knowledge). The course textbook ${ }^{86}$ was authored by Afet İnan, the historian and adopted daughter of Mustafa Kemal (Atatürk). ${ }^{87}$ While other textbooks were also produced during this period, ${ }^{88}$ we will focus on the Inan textbook, for its story as well as content help illustrate the Republican leaders' efforts to mould Turkey's peoples in their image of 'model citizens'.

The 1931 textbook's notion of citizenship was a 'civic republican' one, defining citizenship within the parameters of solidarism and community. ${ }^{89}$ Whereas the 'liberal' definition of citizenship casts citizenship as a status involving rights accorded to citizens, the 'civic republican' definition casts it as a practice involving responsibilities to the wider society. ${ }^{90}$ As with some other 'nation-states' of the time, Turkey's citizenry was 'regarded as, at best, an eventually educable ward and, at worst, someone prone to derail the national journey with his irrational and provincial proclivities'. ${ }^{91}$

Given the course's objective of fashioning 'civilized' and 'modern' citizens, who would be 'obedient' to the Republic, ${ }^{92}$ the textbook put more emphasis on the duties and obligations of citizens towards the state, and less on citizens' rights. Inan later explained such de-emphasis on citizens' rights with reference to Mustafa Kemal's thinking that every right should be complemented by a duty. ${ }^{93}$ The need to tilt the rights/duties balance towards the latter was formulated previously by the Ottoman intellectual Ziya Gökalp who cautioned:

Do not say 'I have rights';

There is only duty, not right.

A sociologist by training, Gökalp's ideas shaped the thinking of early Republican leaders even after his untimely death in 1924. ${ }^{94}$ The Republican People's Party's motto of this era, 'one language, one culture, one ideal', ${ }^{95}$ was also inscribed into the students' worldview through the civic education textbook. The text's emphasis on fashioning a unified citizen body of 'one language, one culture, one ideal' translated into a less than accepting attitude towards all those who fell short of approximating the Republic's citizen imaginary. Regarding the non-Turkish speakers, the textbook said:

In the current political and social unity of the Turkish nation, some of our citizens are being encouraged to adopt a Kurdish, Circassian, Laz or Bosnian identity, but these misnomers, which are remnants of an autocratic period from the past, have caused nothing but misery among these individuals, with the exception of a backward and brainless few. For these members of the nation also share the same common past, history, ethics and law. ${ }^{96}$

To recapitulate, in the early Republican period, peoples of myriad origins could choose to be 'included'. The ticket of entry was exhibiting willingness to approximate the Republic's citizen imaginary as detailed in the civic education textbook. Such willingness was to be exhibited through not drawing attention to (if not forgetting) one's ethnic/religious/sectarian difference/s. ${ }^{97}$ The narrative of the civic education textbook rendered 'backward' all those who failed or refused to approximate the citizen imaginary. 
Thus, while the textbook constituted an instance of the Republican leadership's stratagem for securing Turkey vis-a-vis the (European) International Society through creating a unified body of citizens, at the same time, it rendered myriad peoples insecure by narrowing the bounds of recognition of and respect for difference.

\section{Turkey's 'Model Citizens': searching for ‘Ontological Security'? 98}

'Ontological security' refers to an individual's identity and his or her ability to maintain who he or she is when faced with challenges. ${ }^{99}$ It may come across as counterintuitive to consider Turkey's 'model citizens' as anything other than secure. Yet, their rigid responses to public expressions of 'difference' by their fellow citizens could be viewed as an instance of their search for 'ontological security' in the face of the latter's avowal of their difference/s. This is partly because Turkey's 'included' citizens' sense of self was a product of a citizen imaginary that was not accepting of public expressions of 'difference'. Another, and perhaps more important, part of the reason was to do with the way in which Turkey's 'model citizens' could become 'included', that is, through learning not to draw attention to (if not to forget) their own difference/s. Arguably, Turkey's 'included' citizens viewed others' expressions of their difference/s as a challenge to their own sense of self. Such expressions of 'difference' included using languages other than Turkish in public places, which sparked the infamous 'Citizen, Speak Turkish!' campaigns of the late 1920s and early 1930s.

The 'Citizen, speak Turkish!' campaigns were directed against the minority citizens and were organized and ran by non-governmental actors such as the Turkish Hearths Association and the Students' Association of the Faculty of Law. ${ }^{100}$ Some citizens actively participated in the 'Citizen, Speak Turkish!' campaigns while some others were complicit in their silence. ${ }^{101}$ The first step in the campaign was taken by the Students' Association of the Faculty of Law in İstanbul. On 13 January 1928, the Students' Association of the Faculty of Law in İstanbul organized a campaign aimed at discouraging the use of languages other than Turkish in public places. ${ }^{102}$ The students put up signs that read, 'We cannot say Turk to people who do not speak Turkish'. ${ }^{103}$ They also resorted to accosting people speaking foreign languages in public places. Those who did not speak Turkish were labelled as 'fake citizens' of the Republic. ${ }^{104}$ The Turkish Hearths Association organized similar campaigns in some other parts of the country. ${ }^{105}$ While many Kurds at the time were non-Turkish speakers, the fact that 'Citizen, speak Turkish!' campaigns were organized in cities and towns populated by minority citizens suggested that the latter were the real targets of this campaign.

The campaigns led to tension and conflict, as the participants did not only suggest that everyone in Turkey should speak Turkish but they also threatened some non-Turkish speakers in an attempt to make them speak Turkish. Some of the activists instigated court cases against some non-Turkish speakers, citing Article 159 of the Turkish Penal Code about 'insulting Turkishness'. ${ }^{106}$ Others called on their fellow citizens to '[e]ither speak Turkish or leave the country'. 
While the 'Citizen, speak Turkish!' campaigns were entirely in line with what the Republican leaders encouraged under the slogan 'one language, one culture, one ideal', the forceful approaches of the youth was eventually met by Ankara's disapproval. As the campaigners began to resort to more and more violent methods, the government intervened and called for a halt. ${ }^{107}$

To recapitulate, Turkey's 'included' citizens are peoples of myriad origins who learned not to draw attention to their difference/s as they were moulded into 'model citizens' of the Republic. As products of the citizen imaginary of the Republic, they, too, were in/ secured as they became increasingly less able to live with 'difference'.

\section{Conclusion}

In Turkey's early Republican practices, we observe both faces of citizenship as a 'conspiracy against the rest of the world' (section 'From subjecthood to citizenship: a process of in/securing'). First, the Lausanne Treaty of 1923, whereby Turkey and Greece agreed to exchange populations, was a product of citizenship practices as an 'international system of population management'. As highlighted in section 'Rethinking the literature on citizenship in Turkey', the population exchange between Greece and Turkey was, in essence, a state-directed movement of ethnic groups, which was endorsed by the (European) International Society as a breakthrough attempt at conflict regulation. ${ }^{108}$ Treaties ending the wars of this era invariably included clauses governing population exchanges. Groups that were considered to be (potentially) disloyal were relocated from one part of the state to another or were expelled from the state altogether. ${ }^{109}$ Those who were not forced to immigrate fled soon after. ${ }^{110}$ Turkey's 'excluded' were insecured as part of this first aspect of citizenship as a 'conspiracy against the rest of the world'.

The second aspect, which is more characteristic of the global South, refers to the postcolonial anxieties of Turkey's early Republican leaders and the choice they made for constructing a unified and cohesive body of citizens. Although Turkey was not colonized, the trauma that was caused by the Ottoman Empire coming to the brink of being dismembered by the European great powers conditioned the thinking of the early Republican leaders. Perhaps more significantly, the experiences and remembrances of late Ottoman Empire and its relations with the (European) International Society shaped their postcolonial anxieties. ${ }^{111}$

Going beyond binary portrayals in everyday debates (included/excluded, security/ insecurity) and mainstream IR assumptions on the relationship between security and citizenship (that states provide security to their citizens and that insecurities originate from outside the state boundaries) allows us to consider the in/securing of myriad citizens. Studying the transition of people from subjecthood to citizenship in the global South as a process of in/securing challenges both the mainstream accounts that see the transition as a moment of security, but also some critical accounts that reduce it to a process of insecuring. Inquiring into the relationship between security and citizenship in global South contexts demands particular attention to 'the international' as well as reflexivity of security. 


\section{Funding}

This research received no specific grant from any funding agency in the public, commercial or not-for-profit sectors.

\section{Notes}

1. Keith Krause and Michael C. Williams, 'From Strategy to Security: Foundations of Critical Security Studies', in Keith Krause and Michael C. Williams (eds) Critical Security Studies: Concepts and Cases (London: University of Minnesota Press, 1997), p. 43.

2. We refer to 'empire' in formal terms, as a group of states/countries ruled over by a single person or state. Not all empires are colonial empires. See Kenneth J. Twitchett, 'Colonialism: An Attempt At Understanding Imperial, Colonial, And Neo-colonial Relationships', Political Studies, 13, 1965, pp. 300-23.

3. By the 'global South', we refer to peoples, social groups and states who have relatively limited capacity in shaping world dynamics that affect their lives in social, political, environmental as well as economic terms.

4. J. Peter Burgess, The Ethical Subject of Security: Geopolitical Reason and the Threat Against Europe (London: Routledge, 2011).

5. Ken Booth, Theory of World Security (Cambridge: Cambridge University Press, 2008), p.110.

6. Bill McSweeney, Security, Identity and Interests: A Sociology of International Relations (Cambridge: Cambridge University Press, 1999).

7. See Sankaran Krishna, Postcolonial Insecurities: India, Sri Lanka, and the Question of Nationhood (Minneapolis, MN: University of Minnesota Press, 1999).

8. Mahmood Mamdani, Citizen and Subject: Contemporary Africa and the Legacy of Late Colonialism (Princeton, NJ: Princeton University Press, 1996).

9. Jorge de Alva quoted in Ania Loomba, Colonialism/Postcolonialism (London: Routledge, 2005), p. 16.

10. Krishna, Postcolonial Insecurities, p. xix.

11. Gerrit W. Gong, The Standard of 'Civilization' in International Society (Oxford: Oxford University Press, 1984). Also see Brett Bowden, The Empire of Civilization: The Evolution of an Imperial Idea (Chicago, IL: The University of Chicago Press, 2009).

12. 'International Society' refers to the notion of society of states formed through the diplomatic practices of the European states from the Treaty of Westphalia onwards. See Hedley Bull and Adam Watson (eds) The Expansion of International Society (Oxford: Clarendon Press, 1984).

13. See David P. Fidler, 'The Return of the Standard of Civilization', Chicago Journal of International Law, 2, 2001, pp. 137-57.

14. See, for example, Shogo Suzuki, 'China's Perceptions of International Society in the Nineteenth Century: Learning More About Power Politics?’ Asian Perspective, 28, 2004, pp. $115-144$.

15. We chose to limit our analysis to the 1923-1946 period not because we consider the shift to the multi-party regime in 1946 to have introduced significant changes in Turkey's citizenship regime. Rather, focusing on this early period allows us to study those practices of in/ security that were tied up with aforementioned processes of transition. Without wanting to underemphasize the significance of reforms that were made in later years of the Ottoman Empire in moving towards a citizenship regime, we focus on the citizen imaginary and practices of the new 'nation-state'.

16. Following World War I, today's Iraq, Syria, Lebanon and Jordan came under the League of Nations mandate administered by France and the United Kingdom. 
17. Pinar Bilgin, 'Securing Turkey Through Western-Oriented Foreign Policy', New Perspectives on Turkey, 40, 2009, pp. 105-25.

18. For a postcolonial perspective on Ottoman imperial practices towards 'the Orient', see Ussama Makdisi, 'Ottoman Orientalism', The American Historical Review, 107(3), 2002, pp. 768-96.

19. In our survey of citizenship practices in Turkey, we have utilized both primary and secondary sources. Our primary sources include legislative acts of successive governments, parliamentary minutes of Grand National Assembly (GNA) of Turkey, party programs and election manifestoes of the Republican People's Party, primary and secondary school level civic education textbooks and the print media (1923-1946). All translations from texts in Turkish are by the authors unless otherwise stated.

20. Selim Deringil, The Well-Protected Domains: Ideology and the Legitimation of Power in the Ottoman Empire, 1876-1909 (London: I.B. Tauris, 1998); Selim Deringil, “"They Live in a State of Nomadism and Savagery": The Late Ottoman Empire and the Post-Colonial Debate', Comparative Studies in Society and History, 45, 2003, pp. 311-42. Also see Makdisi, 'Ottoman Orientalism'.

21. As Grovogui reminded, ideas and concepts may be borrowed, formulated and reformulated. They may also be framed in exactly the same terms as they are found in other contexts. This does not render any less 'genuine' the ideals behind the struggles that utilize those ideas and concepts wherever they happen to be located. See Siba N. Grovogui, Beyond Eurocentrism and Anarchy: Memories of International Order and Institutions (London: Palgrave Macmillan, 2006).

22. Fidler identified the standards of civilization as found in International Law in the nineteenth century:

To be a member of Westphalian civilization, a non-Western country had to become a State that (1) guaranteed basic rights, as understood in the West, for foreign nationals; (2) had an organized political bureaucracy with the capacity to run governmental functions and organize the country for self-defense; (3) had a Western-style domestic system of law, with courts and written codes of law, that administered justice fairly within its territory; (4) had diplomatic resources and institutions to allow the State to engage in international relations; (5) abided by international law; and (6) conformed to the customs, norms, and mores accepted in Western societies.

See Fidler, 'The Return of the Standard of Civilization', p. 141.

23. Quoted in Taha Parla, Türkiye'de Siyasal Kültürün Resmi Kaynakları [The Official Sources of Political Culture in Turkey] (İstanbul, Turkey: İletişim, 1991), p. 34.

24. Here is the fourth verse of the 10 -verse poem in full:

The lands of the West may be armored with walls of steel/ but I have borders guarded by the mighty chest of a believer./ Recognize your innate strength, my friend!/ And think: how can this fiery faith ever be killed/ by that battered, single-fanged monster you call civilization?

25. Also see Peter Nyers (ed.) Securitizations of Citizenship (London: Routledge, 2009); Barry Hindess, 'Citizenship for All', Citizenship Studies, 8(3), 2004, pp. 305-15.

26. See, for example, Ken Booth (ed.) Critical Security Studies and World Politics (Boulder, CO: Lynne Rienner Publishers, 2005); Booth, Theory of World Security; Keith Krause and Michael C. Williams (eds) Critical Security Studies: Concepts and Cases (London: University of Minnesota Press, 1997); Barry Buzan, Ole Waever and Jaap De Wilde, Security: A New Framework of Analysis (Boulder, CO: Lynne Rienner, 1998). 
27. See, for example, Cynthia Enloe, Bananas, Beaches and Bases: Making Feminist Sense of International Politics (Berkeley, CA: University of California Press, 1990); Ken Booth, 'Security and Emancipation', Review of International Studies, 17, 1991, pp. 313-26.

28. See, for example, Andrew Linklater, Men and Citizens in the Theory of International Relations (New York: St. Martin's Press, 1982); cf. R.B.J. Walker, 'The Subject of Security', in Keith Krause and Michael C. Williams (eds) Critical Security Studies: Concepts and Cases (London: University of Minnesota Press, 1997), pp. 61-82.

29. See, for example, Roxanne L. Doty, 'Immigration and the Politics of Security', Security Studies, 8, 1998, pp. 71-93; Jef Huysmans, The Politics of Insecurity: Fear, Migration, and Asylum in the EU (London: Routledge, 2006); Cynthia Weber, 'Citizenship, Security, Humanity', International Political Sociology, 4, 2010, pp. 80-85; Xavier Guillaume and Jef Huysmans (eds) Security and Citizenship: The Constitution of the Political Being (London: Routledge, 2012).

30. Charles Tilly (ed.) Citizenship, Identity, and Social History (Cambridge: Cambridge University Press, 1996); Ediberto Roman, Citizenship and its Exclusions (New York: New York University Press, 2010).

31. Claire Rasmussen and Michael Brown, 'Radical Democratic Citizenship: Amidst Political Theory and Geography', in Engin F. Işın and Bryan S. Turner (eds) Handbook of Citizenship Studies (London: SAGE, 2002), pp. 175-88. Also see David Sibley, Geographies of Exclusion: Society and Difference in the West (London: Routledge, 1995).

32. Krishna, Postcolonial Insecurities; Mamdani, Citizen and Subject.

33. S.A. Marston, 'Who Are 'The People'? Gender, Citizenship, and the Making of the American Nation', Environment and Planning D: Society and Space, 8(4), 1990, pp. 441-50.

34. Also see Deniz Kandiyoti, 'Emancipated but Unliberated? Reflections on the Turkish Case', Feminist Studies, 13, 1987, pp. 317-38.

35. Anna Secor, "“There is an İstanbul that Belongs to Me": Citizenship, Space and Identity in the City', Annals of the Association of American Geographers, 94(2), 2004, p. 355.

36. Sibley, Geographies of Exclusion.

37. Sibley, Geographies of Exclusion.

38. Secor, ("There is an Istanbul that Belongs to Me," p. 353) employs the term "citizenstrangers' to analyze those citizens who find themselves estranged from the public sphere and thus less-than-fully able to exercise their constitutionally defined rights. Étienne Balibar ('Historical Dilemmas of Democracy and Their Contemporary Relevance for Citizenship', Rethinking Marxism, 20(4), 2008, pp. 522-38) refers to the same phenomenon as 'internal exclusion'.

39. Barry Hindess, 'Citizenship in the International Management of Populations', American Behavioral Scientist, 43(9), 2000, p. 1496.

40. Hindess, 'Citizenship in the International Management of Populations', p. 1488.

41. Christine Helliwell and Barry Hindess, 'The Empire of Uniformity and the Government of Subject Peoples', Cultural Values, 6(1-2), 2002, pp. 139-52.

42. Mamdani, Citizen and Subject.

43. Barry Hindess, 'The Past is Another Culture', International Political Sociology, 1(4), 2007, p. 326.

44. Hindess, 'The Past is Another Culture'.

45. Edward W. Said, Orientalism (New York: Pantheon, 1978), Joanne P. Sharp, Geographies of Postcolonialism: Spaces of Power and Representation (London: SAGE, 2008).

46. Siba N. Grovogui, Sovereigns, Quasi-Sovereigns and Africans (Minneapolis, MN: University of Minnesota Press, 1996).

47. See, for example, Grovogui, Sovereigns, Quasi-Sovereigns and Africans; Grovogui, Beyond Eurocentrism and Anarchy. 
48. Krishna, Postcolonial Insecurities.

49. Also see Harris Mylonas, The Politics of Nation-Building: Making Co-Nationals, Refugees, and Minorities (Cambridge: Cambridge University Press, 2013).

50. See, for example, Stephen P. Ladas, Exchange of Minorities: Bulgaria, Greece, and Turkey (New York: Macmillan Company, 1932); Kemal Arı, Büyük Mübadele [The Great Exchange] (İstanbul, Turkey: Tarih Vakfi Yurt Yayınları, 2003); Müfide Pekin (ed.) Yeniden Kurulan Yaşamlar: 1923 Türk-Yunan Zorunlu Nüfus Mübadelesi [Re-Constructed Lives: the 1923 Forced Population Exchange Between Greece and Turkey] (İstanbul, Turkey: Bilgi Üniversitesi, 2005).

51. Mesut Yeğen, 'Citizenship and Ethnicity in Turkey', Middle Eastern Studies, 40(6), 2004, pp. 51-66; Mesut Yeğen, "Prospective-Turks" or "Pseudo-Citizens": Kurds in Turkey', Middle East Journal, 63(4), 2009, pp. 597-615.

52. Gürcan Koçan and Ahmet Öncü, 'Citizen Alevi in Turkey: Beyond Confirmation and Denial', Journal of Historical Sociology, 17(4), 2004, pp. 465-89; Tord Olsson, Elisabeth Özdalga and Catarina Raudvere (eds) Alevi Identity: Cultural, Religious and Social Perspectives (İstanbul, Turkey: Swedish Research Institute, 1998).

53. See Arus Yumul, 'Ermeniler Millet-i Sadakat mı, Beşinci Kol mu, Geçmişin Yadigarları mı? [Are Armenians the Loyal Nation, the Fifth Column, or a Remembrance of the Past?]', in Ali Berktay and Hamdi Can Tuncer (eds) Tarih Eğitimi ve Tarihteki Öteki Sorunu [History Education and the Problem of the Other in History] (İstanbul, Turkey: Tarih Vakfi Yurt Yayınları, 1998), pp. 85-97; Arus Yumul, 'Azınlık mı Vatandaş mı? [Minority or Citizen?]', in Ayhan Kaya and Turgut Tarhanlı (eds) Türkiye'de Çoğunluk ve Azınlık Politikalarl: $A B$ Sürecinde Yurttaşlık Tartışmaları [Majority and Minority Policies in Turkey: Citizenship Debates in the EU Process] (İstanbul, Turkey: TESEV, 2005), pp. 87-100; Bora İşyar, 'The Origins of Turkish Republican Citizenship: The Birth of Race', Nations and Nationalism, 11(3), 2005, pp. 343-60; Rıfat Bali, Cumhuriyet Yıllarında Türkiye Yahudileri: Bir Türkleştirme Serüveni 1923-1945 [Turkish Jews in the Republican Era: An Adventure of Turkification, 1923-1945] (İstanbul, Turkey: İletişim Yayınları, 2003).

54. The Republic of Turkey was established on 29 October 1923. On 20 April 1924, the new Republic adopted its first Constitution. For the full text, see '1924 Teşkilat-1 Esasiye Kanunu' [1924 Turkish Constitution] Düstur, Tertip: 3, Cilt: 5, p. 576.

55. See, for example, Suna Kili and Gözübüyük A. Şeref, Türk Anayasa Metinleri: Sened-i Ittifaktan Günümüze [Turkish Constitutional Documents from the Charter of Alliance of 1808 to the Present] (Ankara, Turkey: Türkiye İş Bankası Kültür Yayınları, 2000); Bülent Tanör, Osmanl-Türk Anayasal Gelişmeleri [Ottoman-Turkish Constitutional Developments] (İstanbul, Turkey: Yapı Kredi Yayınları, 2001); Suna Kili, Türk Anayasaları [Turkish Constitutions] (İstanbul, Turkey: Tekin Yayınevi, 1984); Suna Kili, Kemalism (İstanbul, Turkey: Menteş Matbaası, 1969). For a critical reading of the founding texts, see, Mesut Yeğen, 'Yurttaşlık ve Türklük [Citizenship and Turkishness]', Toplum ve Bilim, 93, 2002, pp. 200-17; Erol Ülker, 'Assimilation of the Muslim Communities in the First Decade of the Turkish Republic (1924-1934)', European Journal of Turkish Studies (Online), available at: /index2123.html (accessed 1 July 2014).

56. Those who were not included in the population exchange.

57. This is not to underestimate significant attempts made during later decades of the Ottoman Empire towards creating an 'inclusive' security regime. On the continuities between late Ottoman and early Republican citizenship practices, see Işın, 'Citizenship after Orientalism'; Feyzi Baban, 'Community, Citizenship and Identity in Turkey', in Fuat Keyman and Ahmet İçduygu (eds) Citizenship in a Global World (London: Routledge, 2005), pp. 52-70; Selim Deringil, 'The Ottoman Origins of Kemalist Nationalism: Namık Kemal to Mustafa Kemal', European History Quarterly, 23(2), pp. 165-91. 
58. Yeğen, 'Yurttaşlik ve Türklük', p. 215, suggested that Turkey's early Republican leaders never intended to 'include' the minority citizens and were ambivalent (at best) towards some religious and ethnic groups as with the Kurds and the Alevi. Article No.4 of the Civil Service Law No. 788 indeed stipulated that all civil servants must be 'Turkish'. That having been said, the definition of 'Turkishness' was fluid then as now. Therefore, we included the non-Muslim minorities in our category of 'included/excluded' to be able to point to in/ securing of different facets of Turkey's citizens.

59. See Pinar Bilgin, 'The Securityness of Secularism? The Case of Turkey', Security Dialogue, 39(6), p. 603.

60. Bilgin, 'The Securityness of Secularism?' pp. 602-9.

61. See, for example, Yumul, 'Ermeniler Millet-i Sadakat mı, Beşinci Kol mu, Geçmişin Yadigarları mı?'; Feyzi Baban, 'The Public Sphere and the Question of Identity in Turkey', in E. Fuat Keyman (ed.) Remaking Turkey: Globalization, Alternative Modernities, and Democracy (Lanham, MD: Lexington Books, 2007), pp. 75-99; Koçan and Öncü, 'Citizen Alevi in Turkey'; Betigül Ercan Argun, 'Universal citizenship rights and Turkey's Kurdish question', Journal of Muslim Minority Affairs, 19(1), 1999, pp. 85-103; Yumul, 'Azınlık m1 Vatandaş mı?'; Yeğen, 'Citizenship and Ethnicity in Turkey’; Yeğen, “'Prospective-Turks”' or "Pseudo-Citizens?"”

62. Kandiyoti, 'Emancipated but Unliberated?'

63. Yüksel Akkaya, 'Türkiye' de Türk Vatandaşlarına Tahsis Edilen Sanat ve Hizmetler Hakkında Kanun: 1929 Bunalımı, İşsizlik ve Bir Kanun [Law Regarding Artisanry and Services Assigned to Turkish Citizens in Turkey: The Great Depression of 1929, Unemployment and a Law]', Toplumsal Tarih, 68, 1999, pp. 42-52; Bali, Cumhuriyet Yıllarında Türkiye Yahudileri.

64. Rifat Bali, The 'Varlık Vergisi'Affair: A Study on Its Legacy-Selected Documents (İstanbul, Turkey: Isis Press, 2005); Rifat Bali, Yirmi Kur'a Nafia Askerleri [The Incident of the 20 Classes] (İstanbul, Turkey: Kitabevi, 2008); Bali, Cumhuriyet Yıllarında Türkiye Yahudileri.

65. İlhan Tekeli, 'Osmanlı İmparatorluğu'ndan Günümüze Nüfusun Zorunlu Yer Değiştirmesi ve İskan Sorunu' [Forced Population Exchange and the Problem of Settlement, From the Ottoman Empire to the Present], Toplum ve Bilim, 50, 1990, pp. 49-71.

66. The Lausanne Treaty followed the successes of the war of national liberation and revised the Treaty of Sèvres. The population exchange between Turkey and Greece was proposed by the European great powers as a conflict prevention/resolution measure. See the concluding section for further discussion. Also see Lozan Barış Konferansı Tutanaklar-Belgeler [Lausanne Peace Conference: Minutes-Documents], vol. 1, Book. 1 (İstanbul, Turkey: YKY, 2001), pp. 174-175.

67. Umut Özsu, 'Fabricating Fidelity: Nation-Building, International Law, and the GreekTurkish Population Exchange', Leiden Journal of International Law, 24, 2011, pp. 823-847.

68. Özsu, 'Fabricating Fidelity', p.825.

69. Quoted in Ayhan Aktar, 'Türk Yunan Nüfus Mübadelesi’nin İlk Y111: Eylül 1922-Eylül 1923' [The First Year of the Turkish-Greek Population Exchange] in Müfide Pekin, ed. Yeniden Kurulan Yaşamlar: 1923 Türk-Yunan Zorunlu Mübadelesi [Lives Re-constructed: 1923 Turkish-Greek Forces Population Exchange] (İstanbul, Turkey: Bilgi Üniversitesi Yayınları, 2005), p.73. For a powerful portrayal of the population exchange and the predicament of the 'excluded', also see the documentary directed and produced by Ömer Aşan, (2012) Kardeş Nereye: Mübadele [Where Are You Going Bro: The Exchange]. Also see İsmet Pasha and Venizelos headed Turkish and Greek delegations at the Lausanne negotiations, see Note 50.

70. This is not to overlook women, whose predicament was characterized by Deniz Kandiyoti as 'emancipated but unliberated'. See Kandiyoti, 'Emancipated but Unliberated?' 
71. 'Ískan Kanunu' [Settlement Law], No: 885, 31/06/1926, Düstur, Tertip: 3, Cilt: 7, pp. 1441-43.

72. 'Ískan Kanunu' [Settlement Law], No: 2510, 14/06/1934, Düstur, Tertip: 3, Cilt: 15, pp. 1156-75.

73. Some scholars pointed to the ways in which the legal discourse of admitting immigrants was not tallied with practices. The legal formulation of 'Turkish descent and culture' that stressed ethnic affiliation and language, remaining silent with regards to religion, did not correspond to the real practices that were oftentimes in favour of immigrants with SunniHanefi religious background. See, for example, Kemal Kirişçi, 'Disaggregating Turkish Citizenship and Immigration Practices', Middle Eastern Studies, 36(3), 2000, pp. 1-22.

74. 'İskan Kanunu, No: 2510', p. 1156.

75. Ülker ('Assimilation of the Muslim communities') suggested that although the emphasis on ethnicity was more explicit in the settlement law of 1934 (when compared to past laws), it nevertheless exhibited continuity with past practice in that the Republican leaders' search for a unified polity was reflected in the immigration-settlement policies previous years.

76. TBMM Zabıt Ceridesi, Devre: IV, Cilt: 23, İçtima: 3 (14 June 1934), p. 141.

77. Sibel Bozdoğan, 'Architecture, Modernism and Nation-Building in Kemalist Turkey', New Perspectives on Turkey, 10, 1994, pp. 37-55; Zeynep Kezer, 'An Imaginable Community: The Material Culture of Nation-Building in Early Republican Turkey', Environment and Planning D: Society and Space, 27, 2009, pp. 508-30. But see Amy Mills, 'Boundaries of the Nation in the Space of the Urban: Landscape and Social Memory in Istanbul', Cultural Geographies, 13(3), 2006, pp. 376-94.

78. Martin Coward, 'Against Anthropocentrism: The Destruction of the Built Environment as a Distinct Form of Political Violence', Review of International Studies, 32(3), 2006, pp. 419-37.

79. See, for example, Arzu Öztürkmen, 'Remembering Through Material Culture: Local Knowledge of Past Communities in a Turkish Black Sea Town', Middle Eastern Studies, 39, 2003, pp. 179-193.

80. Kerem Öktem, 'The Nation's Imprint: Demographic Engineering and the Change of Toponymes in Republican Turkey', European Journal of Turkish Studies (Online), available at: http://ejts.revues.org/2243 (accessed: 24 August 2012).

81. During the 1940 s, preparations began to be made for a large-scale name change action throughout the country. With Law No. 5542 passed in 1949, such changes were given a legal basis in national legislation.

82. Yeğen, 'The Kurdish Question in Turkish State Discourse', Journal of Contemporary History, 34(4), 1999, pp. 555-68, reads the term 'lifestyle' as code word for Kurdish in the official lexicon of the Republic. What he does not underscore is that such unaccepting attitude towards different lifestyles constituted an instance of in/securing for all nomads. While (re)settlement allowed access to education and healthcare, it, at the same time, undermined nomadic aspects of their culture.

83. Michael J. Shapiro, 'Nation-States', in John Agnew, Katharyne Mitchell and Gearoid O. Tuathail (eds) A Companion to Political Geography (Oxford: Blackwell, 2003), pp. 278.

84. İlker Aytürk, 'Turkish Linguists against the West: The Origins of Linguistic Nationalism in Atatürk’s Turkey', Middle Eastern Studies, 40(6), 2004, pp. 1-25.

85. In 1923, approximately 3 per cent of the overall population was in primary, secondary and high schools combined. By 1935-1936, this ratio had increased to 4.4 per cent. See Necdet Sakaoğlu, Osmanlı'dan Günümüze Eğitim Tarihi [The History of Education from the Ottomans until the Present] (İstanbul, Turkey: Bilgi Üniversitesi Yayınları, 2003). Therefore, the impact of the civic education course was limited to a narrow portion of the populace. 
86. Afet İnan, Vatandaş Iç̧in Medeni Bilgiler [Civic Information for the Citizen] (İstanbul, Turkey: Devlet Matbaas1, 1931).

87. İnan reported that Mustafa Kemal, upon seeing the Yurt Bilgisi textbook she was using, did not find it sufficient and commissioned her to write a new one. Mustafa Kemal also asked for translations of the French and German textbooks, personally read them and gave dictation to İnan, thereby authoring significant portions of the book. See Afet İnan, Medeni Bilgiler ve Mustafa Kemal Atatürk'ün El Yazlları [Civic Information for the Citizen and Atatürk's Manuscripts] (Ankara, Turkey: Türk Tarih Basımevi, 1969).

88. Muallim Abdülbaki, Yurt Bilgisi [Homeland Knowledge] (İstanbul, Turkey: Maarif ve Şark Kitaphaneleri, 1927-1928); Kazım Sevinç, Türk Yavrularına Yurt Bilgisi: Sinıf 5 [Homeland Knowledge for the Turkish Children: 5th Grade] (İstanbul, Turkey: Ekspres Matbaası, 1931); Tezer Taşkıran, Yurt Bilgisi I [Homeland Knowledge I] (İstanbul, Turkey: Maarif Matbaas1, 1939); Bedia Ermat and Kemal Ermat, Yurt Bilgisi Dersleri: IV. Sinif [Lectures of Homeland Knowledge: 4th Grade] (İstanbul, Turkey: Milli Eğitim Basımevi, 1943).

89. İnan, Vatandaş İçin Medeni Bilgiler.

90. Charles Taylor, 'The Liberal-Communitarian Debate', in Nancy L. Rosenblum (ed.) Liberalism and the Moral Life (Cambridge, MA: Harvard University Press, 1989), pp. 159-83.

91. Krishna, Postcolonial Insecurities. On Turkey, see Ayse Kadığlu, 'An Oxymoron: The Origins of Civic-Republican Liberalism in Turkey', Critique: Critical Middle Eastern Studies, 16 (2007), 171-190.

92. İnan, Vatandaş İçin Medeni Bilgiler.

93. İnan, Medeni Bilgiler ve Mustafa Kemal Atatürk'ün El Yazılart.

94. See Taha Parla, The Social and Political Thought of Ziya Gökalp, 1876-1924 (Leiden. The Netherlands: E.J. Brill, 1985).

95. The 1931 program of the Republican People's Party defined nation as a 'political and social community formed by citizens bound by a unity of language, culture and ideal'. See Başak İnce, Citizenship and Identity in Turkey: From Atatürk's Republic to the Present Day (London: I.B. Tauris, 2012), p. 73.

96. İnan, Vatandaş İçin Medeni Bilgiler.

97. That said, some who learned not to declare their difference/s still found themselves among the 'included/excluded' citizens of Turkey. For an account on the experiences of the former, see Baban, 'The Public Sphere and the Question of Identity in Turkey'. For the latter, see Fethiye Çetin, Anneannem [My Grandmother] (İstanbul, Turkey: İletişim, 2004).

98. This aspect of the argument is further developed in Pinar Bilgin and Basak Ince, 'Ontological (In)security of "Included” Citizens: The Case of Early Republican Turkey (1923-46)' in Bahar Rumelili (ed.) Ontological Security and Conflict Resolution (Routledge, in press).

99. Anthony Giddens, Modernity and Self-Identity: Self and Society in Late Modern Age (Oxford: Polity Press, 1991); Catarina Kinnvall, 'Globalization and Religious nationalism: Self, Identity, and the Search for Ontological Security', Political Psychology, 25(5), 2004, pp. 741-67; Jennifer Mitzen, 'Ontological Security in World Politics: State Identity and the Security Dilemma’, European Journal of International Relations, 12(3), 2006, pp. 341-70.

100. Their close relationship to the Republican People's Party is viewed by some as evidence of governmental involvement in the organization of the 'Citizen, Speak Turkish!' campaigns. On the close relationships between early Republican cadres and ideologies and the Turkish Hearts Associations, see Füsun Üstel, Imparatorluktan Ulus- Devlete Türk Milliyetçiliği: Türk Ocaklar (1912-1931) [Turkish Nationalism from Empire to Nation-State: Turkish Hearts (1912-1931)] (İstanbul, Turkey: İletişim, 1997). 
101. Equally significant is the 6-7 September 1955 riots against minority citizens, which is beyond the scope of this article. See Rifat Bali, 6-7 Eylül 1955 Olaylarl [6-7 September 1955 Events] (İstanbul, Turkey: Libra Kitapçılık, 2010); M. Hulusi Dosdoğru, 6/7 Eylül Olaylarl [6/7 September Events] (İstanbul, Turkey: Bağlam Yayınları, 1993); Dilek Güven, 6-7 Eylül 1955 Olayları [6-7 September 1955 Events] (İstanbul, Turkey, İletişim, 2005).

102. Orhan Seyfi Orhon, 'Vatandaş Türkçe Konuşma! ['Citizen, Do not Speak Turkish!'], Akbaba, 341, 1941, p. 1-3.

103. Orhon, 'Vatandaş Türkçe Konuşma!', p. 2.

104. Orhon, 'Vatandaş Türkçe Konuşma!', p. 3.

105. M. Çağatay Okutan, Milli Türk Talebe Birliği [Turkish National Students’ Union] (İstanbul, Turkey: Bilgi Üniversitesi Yayınları, 2004).

106. Bali, Cumhuriyet Ylllarında Türkiye Yahudileri.

107. Senem Aslan, “"Citizen, Speak Turkish!”: A Nation in the Making', Nationalism and Ethnic Politics, 13(2), 2007, p. 254.

108. See John McGarry, "Demographic Engineering”: the State-Directed Movement of Ethnic Groups as a Technique of Conflict Regulation', Ethnic and Racial Studies, 21, 1998, pp. 613-38; John McGarry and Brendon O'Leary, 'The Political Regulation of National and Ethnic Conflicts', Parliamentary Affairs, 47, 1994, pp. 94-115.

109. McGarry, 'Demographic Engineering', p. 613.

110. During 1918-1923, the Ottoman Empire received refugees arriving from the Balkan and Caucasian states and Russia. Most immigrants Turkey received between and 1923 and 1950 were objects of demographic engineering practices of other Balkan states.

111. On the continuities between late Ottoman and early Republican periods, see Deringil, 'The Ottoman Origins of Kemalist Nationalism'; Feroz Ahmad, The Young Turks: The Committee of Union and Progress in Turkish Politics 1908-1914 (Oxford: Clarendon Press, 1969); Erik Jan Zürcher, The Young Turk Legacy and Nation Building: From the Ottoman Empire to Atatürk's Turkey (London: I.B. Tauris, 2010).

\section{Author Biographies}

Pinar Bilgin is an Associate Professor of International Relations at Bilkent University. She specializes in critical approaches to security. She is the author of Regional Security in the Middle East: A Critical Perspective (2005) and The International in Security, Security in the International (forthcoming).

Basak Ince is an Assistant Professor in the Department of Political Science and Public Administration at Bilkent University. She is the author of Citizenship and Identity in Turkey: From Atatürk's Republic to the Present Day (2012). 